\title{
Menggali Ideologi Ki Hajar dalam Pendidikan Seni
}

Dadang Hernawan Hadliansah \& J. Julia

\begin{abstract}
Abstrak
Tulisan ini memaparkan tentang pemikiran Ki Hajar Dewantara mengenai pendidikan kesenian di Indonesia. Inti dari pemikirannya, bahwa pendidikan kesenian di Indonesia, selain meningkatkan aspek keterampilan atau intelektualitas, juga harus dapat memperindah budi pekerti atau mempercantik karakter dari peserta didik.
\end{abstract}

Kata kunci: Pendidikan, seni, karakter, Ki Hajar, budi pekerti.

\section{A. Pendahuluan}

Meskipun agak terlambat, melalui kurikulum tingkat satuan pendidikan (KTSP), pemerintah mulai memberikan ruang bagi pengembangan pendidikan seni (baca: kebudayaan) nusantara yang selama ini termarjinalkan dan teralienasi dari kehidupan generasi muda kita. Munculnya materi seni daerah setempat dan seni nusantara pada KTSP selain sebagai upaya mengangkat kembali seni budaya tradisi, adalah juga satu wujud kesadaran pemerintah akan arti pentingnya implementasi pluralisme budaya masyarakat dengan konsep kurikulum multikultural (Hasan, 2000) dan semangat multicultural education (Louis \& Alan Cohen -ed., 1986) dalam pendidikan nasional.

Akibat kurangnya perhatian terhadap eksistensi seni budaya daerah dalam pendidikan, kita melihat bahwa beberapa dasawarsa ini pendidikan seni bersifat stereotype atas pendidikan seni "Barat". Materi kurikulum dipenuhi oleh muatan-muatan kebudayaan "Barat" sehingga seni yang berakar pada sendi-sendi kebudayaan sendiri dianggap kampungan, kuno, ketinggalan jaman, tidak up to date. Bahkan muncul kesan pada masyarakat kita bahwa kalau tidak datang dari "Barat" tidak "gaul”, tidak modern. Tentu saja semua itu menjerumuskan siswa pada semakin jauhnya mereka dari sendi-sendi kehidupan bangsa Indonesia, gotong-royong, kesopanan, kesantunan, dan kerja keras yang dulu dibanggakan bangsa-bangsa Timur -termasuk Indonesia- tidak lagi tampak. Tradisi semakin terasing di negeri sendiri, lestari di museum, dan hanya sebatas nostalgia indah 
keagungan masa lalu. Tinggalah sifat individualistik, kekerasan, tawuran, narkoba, dan seks bebas layaknya kehidupan nun jauh di seberang sana yang menjadi makanan sehari-hari para pelajar kita.

Padahal jauh sebelum ini terjadi, R. M. Suwardi Soeryaningrat, Bapak Pendidikan Indonesia yang lebih dikenal dengan nama Ki Hajar Dewantara sudah mewasiatkan seni tradisional sebagai salah satu landasan arah gerak pengembangan pendidikan nasional. Dalam dua bukunya yang bertajuk Pendidikan (1962) dan Kebudayaan (1967) yang diterbitkan oleh Madjelis Luhur Persatuan Taman Siswa, Ki Hajar menjelaskan dengan gamblang konsep dasar, tujuan, dan pola pendidikan seni yang didasarkan atas sari pati kebudayaan bangsa dalam rangka menopang pendidikan nasional.

\section{B. Konsep Dasar Pendidikan Seni}

Pemikiran Ki Hajar Dewantara mengenai pendidikan seni merupakan implementasi atas hasil kontemplasinya terhadap hakekat kehidupan manusia selaku makhluk berperadaban dan berbudaya. Beliau mendefinisikan peradaban sebagai segala gerak jiwa dan raga manusia yang mencerminkan sifat-sifat keluhuran dan kehalusan, sedangkan kebudayaan merupakan kemampuan atau kesanggupan manusia untuk mencipta segala sesuatu yang mengandung sifat-sifat keluhuran dan keindahan itu. Sehingga keluhuran, kehalusan, dan keindahan senantiasa selalu nampak dalam kehidupan lahir dan batin manusia.

Mengingat bahwa pendidikan merupakan salah satu sarana transformasi budaya, maka kesenian yang nota bene merupakan bagian integral dalam hidup kebudayaan, semestinya mendapat peranan istimewa dalam proses mendidik dan mengajar anak-anak (siswa). Seni harus menjadi sarana membina pribadi siswa menurut pola dasar kebudayaannya, yaitu kebudayaan di mana ia hidup dan bermain di dalamnya. Sehingga wajah pendidikan pada satuan pendidikan akan mencerminkan pola kehidupan budaya dari siswa yang menjadi stakeholder-nya.

Pada hakekatnya, Ki Hajar Dewantara memberikan pemaknaan pendidikan sebagai upaya membina peserta didik dari segi intelektual, emosi, dan kemauan yang bertujuan untuk mencerdaskan otak, menghaluskan budi, dan menyehatkan 
badan. Pendidikan intelektualitas merujuk pada upaya menuntun peserta didik agar menjadi lebih cerdas secara kognitif sehingga memiliki pemahaman dan penalaran tinggi atas fenomena-fenomena kehidupan sehubungan dengan sains dan teknologi. Pendidikan emosi berfungsi menghaluskan budi secara afektif sehubungan rasa kesopanan, kesusilaan, keindahan, dan sisi-sisi kejiwaan lainnya. Sementara pendidikan kemauan merujuk pada upaya mendorong siswa secara motorik agar mau berusaha dan berupaya maksimal atas segala sesuatu yang ia butuhkan dalam kehidupannya.

Tiga komponen ini merupakan trinitas atau trilogy pendidikan yang seharusnya menjadi acuan secara integral dan menyeluruh dalam pendidikan Indonesia. Artinya tidak ada anggapan bahwa satu aspek merupakan bagian terpenting dari aspek lainnya melainkan semua aspek memiliki kedudukan sama serta saling berkaitan dan saling pengaruhi antara satu dengan lainnya. Atas dasar itulah maka posisi pendidikan kesenian memiliki peranan setara dengan bidang studi lainnya dalam tataran dunia pendidikan sebagaimana yang telah diperjuangkan oleh Ki Hajar Dewantara melalui Perguruan Taman Siswa-nya.

\section{Tujuan Pendidikan Seni}

Pendidikan seni merupakan alternatif dalam memperkenalkan kesenian yang berakar pada budaya bangsa, sekaligus sebagai filter masuknya budaya asing yang gencar menghantam kebudayaan kita. Selain itu, juga merupakan upaya penyeimbang atas membludaknya pengutamaan pendidikan pada sisi intelektulitas saja. Pendidikan kesenian memiliki manfaat bagi kecerdasan jiwa dari siswa yang mampu menghaluskan serta memperdalam gerak-gerik jiwa sehingga diharapkan dapat memperbaiki sifat budi pekerti siswa. Dengan demikian keseimbangan pembinaan peserta didik baik dari sisi kesarjanaan maupun kesujanaan dapat tercapai dengan baik.

Determinasi seni untuk seni dalam pendidikan kita terasa belum lengkap. Filosofi pendidikan seni tidak sebatas pendidikan seni sebagai pendidikan estetis sebagaimana diungkapkan Elliot (1994) melainkan estetis hanyalah merupakan satu bagian dari seni dalam kebudayaan Indonesia. Kebanyakan seni tradisi pada 
kebudayaan kita tidak berbicara masalah estetika sebagai subject matter atau teks seni saja, melainkan disertai konteksnya dalam masyarakat dengan sejuta makna fenomenologis di dalamnya.

Berdasarkan konsep-konsep dasar pendidikan seni sebagaimana diuraikan di atas, maka dari pemikiran Ki Hajar Dewantara dapat ditarik benang merahnya bahwa pendidikan kesenian bertujuan sebagai salah satu upaya dalam rangka memberi pengaruh baik terhadap perkembangan hidup anak-anak (peserta didik), secara jasmani dan rohani. Terutama untuk menjaga jangan sampai bangsa ini terdidik semata-mata dalam suasana penalaran atau intelektulitas karena akan berdampak pada munculnya sikap individualisme dan materialisme membabi buta.

\section{Pola Pendidikan Seni}

Pola pengajaran seni yang dikemukakan oleh Ki Hajar Dewantara menggunakan materi seni tradisi dari sisi teks dan konteksnya, makna dan wujudnya dalam kehidupan masyarakat. Pendidikan seni musik misalnya, pengajaran beliau mengacu pada filosofi pengajaran "Sastra Gending" Sultan Agung Mataram. Beliau memberikan istilah sebagai "Metode Sariswara" yaitu metode pembelajaran sastra (bahasa) melalui nyanyian di mana keduanya menjadi bagian integral dari pembelajaran. Berdasarkan penjelasannya mengenai hubungan syair dan melodi sebagaimana pengajaran "sastra dan gending" dari Sultan Agung, maka dapat disimpulkan bahwa peranan ritme (irama), syair lagu (bahasa) dan upaya kebersamaan untuk melantunkannya merupakan pengejawantahan atas konsep trinitas pendidikan sebagaimana dijelaskan di atas.

Perubahan ritme atau irama dalam lagu dan gending pada nyanyian anakanak seperti cepat-lambat, keras-halus, kuat dan lemah secara runut dan harmonis memberikan kesan hidup. Sehingga irama atau ritme menumbuhkan semangat pada peserta didik yang bermanfaat bagi kehalusan perasannya. Sementara syair jelas-jelas mengutamakan daya pikir atau nalar peserta didik atas pengajaran bahasa. Serta di balik itu semua, ketika satu nyanyian dilantunkan maka akan menuntun peserta didik untuk berupaya dan berusaha agar dapat menyanyikannya 
dengan benar. Bagi siswa yang suaranya tidak sama, maka dia akan berupaya agar suaranya sama dengan sang guru atau siswa lainnya. Nah, upaya-upaya ini menunjukkan kemauan dari peserta didik, mau bisa atau tidak!

Dalam pendidikan seni gerak (tari) beliau mengangkat fenomena tari "Srimpi", tarian halus keraton sebagai contoh. Tari "Srimpi" merupakan salah satu genre seni yang indah dan berasal dari bercampurnya "religie" dan "kunst" yakni rasa kebatinan suci dan rasa keindahan, gerak-geraknya halus mengalir lemah lembut dan gemulai menunjukan kesucian serta ketertiban, dan dipelajari serta ditarikan hanya oleh gadis-gadis "beradab" dari lingkungan istana raja sekaligus sebagai kalangenan raja-raja pada jamannya.

Karena sifat-sifatnya itu, Ki Hajar menjadikan tari "Srimpi” sebagai materi pelajaran seni di sekolah. Beliau berasumsi bahwa jika seni hanya dimiliki keraton maka ia tidak dapat berkembang dengan baik, hanya akan tersimpan, dan tidak menjadi milik nasional serta lama kelamaan akan musnah seiring memudarnya aura keraton itu sendiri. Kemudian tari "Srimpi" memiliki manfaat untuk menumbuhkan rasa wirahma (ritme) yaitu mengekang diri (zelfbeheersching) dan gerak wiraga yaitu kesusilaan.

Akhirnya, Ki Hajar dan tentu kita semua berharap bahwa pendidikan seni akan mampu menjadi ajang perkenalan, pemahaman, internalisasi nilai, dan jembatan siswa dengan budayanya, sekaligus filter bagi masuknya budaya asing dalam kehidupan generasi muda. Mudah-mudahan!

\section{E. Kesimpulan}

Berdasarkan paparan di atas, dapat disimpulkan bahwa (1) pendidikan kesenian bertujuan sebagai salah satu upaya dalam rangka memberi pengaruh baik terhadap perkembangan hidup anak-anak (peserta didik), secara jasmani dan rohani, dan (2) pola pendidikan seni seyogianya berorientasi pada materi seni tradisi yang ada di lingkungan masyarakat sekitar, dengan pendidikan meliputi kajian teks dan kontekstual. 


\section{Daftar Pustaka}

Dewantara, Ki Hadjar. (1962). Pendidikan. Yogyakarta: Taman Siswa.

Dewantara, Ki Hadjar. (1967). Kebudayaan. Yogyakarta: Taman Siswa.

Elliot, David. J. (1995). Music Matters. New York: Oxford University Press.

Louis Cohen \& Alan Cohen, (ed). (1986). Multicultural Education: a Sourcebook for Teachers. Harper \& Row Ltd: London.

Said Hamid Hasan. (2000). "Pendekatan Multi Kultural Untuk Penyempurnaan Kurikulum Nasional". Jurnal Pendidikan dan Kebudayaan No. 26. Tersedia: www.depdiknas.go.id. 